\title{
PELATIHAN PROGRAM OLAHRAGA KESEHATAN UNTUK PEMELIHARAAN KEBUGARAN JASMANI SISWA SMA DI MASA PANDEMI COVID-19
}

\author{
Robertus Lili Bile 1), Yohanes Bayo Ola Tapo ${ }^{2)}$ \\ 1,2)Pendidikan Jasmani Kesehatan \& Rekreasi, STKIP Citra Bakti \\ 1) robertuslilibile16@gmail.com, ${ }^{2}$ yohanesbayoolatapo@gmail.com
}

\section{Histori artikel}

Received:

09 Februari 2021

Accepted:

31 Maret

Published:

19 April 2021

\begin{abstract}
Abstrak
Kegiatan pelatihan ini bertujuan untuk memberikan pelatihan program olahraga kesehatan untuk pemeliharaan kebugaran jasmani siswa/i tingkat SMA di masa pandemi COVID-19. Substansi kegiatan pengabdian ini meliputi; edukasi pentingnya pemeliharaan kebugaran jasmani selama masa pandemi, pendampingan praktik latihan kebugaran jasmani, serta edukasi mengenai prinsip-prinsip latihan kebugaran jasmani yang baik dan benar meliputi; bentuk latihan, tujuan dan sasaran latihan, intensitas latihan, frekuensi latihan, serta durasi latihan. Siswa/i yang menjadi target kegiatan pengabdian ini adalah siswa/i tingkat SMA yang berada di Desa Naruwolo, Kecamatan Jerebu'u, Kabupaten Ngada. Kegiatan pengabdian ini dilakasanakan dengan menggunakan pendekatan ceramah dan pendampingan praktik secara langsung oleh tim pengabdi. Hasil dari kegiatan pengabdian ini adalah 1) siswa/i memiliki pemahaman yang baik mengenai pentingnya pemeliharaan kebugaran jasmani, 2) menguasai keterampilan latihan fisik untuk pemeliharaan kebugaran jasmani selama pandemi COVID-19, serta 3) memiliki pemahaman mengenai prinsip-prinsip latihan kebugaran jasmani yang baik dan benar meliputi; bentuk latihan, tujuan dan sasaran latihan, intensitas latihan, frekuensi latihan, serta durasi latihan.
\end{abstract}

Kata-kata Kunci: program latihan kebugaran, olahraga kesehatan, pemeliharaan kebugaran jasmani 
Abstract. This training activity aims to provide training in health sports programs for the maintenance of physical fitness for high school students during the Covid-19 pandemic. The substance of this service activity includes; education on the importance of maintaining physical fitness during the pandemic, mentoring in physical fitness practice, as well as education on the principles of good and correct physical fitness training, including; training form, training goals and objectives, training intensity, training frequency, and training duration. Students who are the targets of this service activity are high school students in Naruwolo Village, Jerebu'u District, Ngada Regency. This training activity is carried out using a lecture approach and direct practical assistance by the service team. The results of this training are 1) students have a good understanding of the importance of maintaining physical fitness, 2) master physical exercise skills for maintaining physical fitness during the Covid-19 pandemic, and 3) have an understanding of the principles of physical fitness training well and properly include; training form, training goals and objectives, training intensity, training frequency, and training duration.

Keywords: Fitness exercise program, health sports, physical fitness maintenance

\section{PENDAHULUAN}

Kebugaran jasmani merupakan faktor utama yang mempengaruhi status kesehatan setiap individu (Lipecki \& Rutowicz, 2015:64-65). Secara sederhana, kebugaran jasmani dapat dipahami sebagai kemampuan seseorang dalam melakukan suatu tugas gerak tertentu secara maksimal dan efisien tanpa mengalami kelelahan yang berlebihan serta terhindar dari resiko gangguan kesehatan (Bile \& Suharjana, 2019:31-32). Pada masa pandemi COVID-19, usaha pemeliharaan kebugaran jasmani perlu untuk tetap dilakukan sebagai salah satu tindakan preventif dalam rangka meningkatkan imunitas tubuh secara khusus serta pemeliharaan kesehatan secara umum (Hale et al., 2018:7-8). Tidak dapat dipungkiri bahwa resiko penerapan belajar dari rumah selama pandemi COVID-19 telah banyak berdampak pada kurangnya intensitas aktivitas fisik pelajar pada umumnya tidak terkecuali siswa/i tingkat SMA. Kemudahan dalam melakukan akses informasi materi pembelajaran secara online melalui media smartphone, komputer dan media elektronik lainnya secara tidak langsung berimplikasi pada kondisi rendahnya kinerja aktivitas fisik. Kondisi ini dapat menimbulkan kecenderungan pola hidup sedentary yang akan meningkatkan resiko mengalami gangguan kesehatan seperti obesitas, gangguan pada sistem kardiovaskular, berkurangnya imunitas tubuh serta penyakit degeneratif lainnya (Knaeps et al., 2016:1-2) yang akan mengakibatkan kondisi rentan terserang virus COVID19.

Persoalan ketidakaktifan fisik hingga kini masih menjadi masalah yang kian meluas dengan lebih dari $30 \%$ orang dewasa gagal memenuhi tingkat aktivitas fisik yang memadai (Bachmann et al., 2015:1876-1877). Kondisi ini mengindikasikan bahwa, akumulasi aktivitas fisik dalam sehari melalui pekerjaan rutin ternyata belum cukup untuk menunjang kebugaran jasmani secara umum. Dengan demikian maka dibutuhkan program rutin aktivitas latihan atau olahraga yang dilaksanakan secara sistematis dan bersifat kontinyu (Irianto, 2017:1-3) guna menunjang pemeliharaan kondisi kebugaran fisik (Bile \& Suharjana, 2019:35-36). Upaya pemeliharaan kebugaran jasmani di masa pandemi COVID-19 ini, selain menerapkan 
protokol kesehatan terkait COVID-19 sesuai yang dianjurkan oleh Pemerintah seperti mencuci tangan pakai sabun, memakai masker, hindari kerumunan serta menjaga jarak, juga diperlukan adanya usaha preventif lainnya untuk megantisipasi resiko penularan COVID-19 dikalangan pelajar SMA.

Dalam konteks upaya memerangi penyebaran dan penularan COVID-19, lembaga pendidikan tinggi melalui program tri dharma, perlu melakukan usaha konkret untuk membantu meminimalisir resiko gangguan kesehatan sebagai dampak pandemi COVID-19 di kalangan pelajar. Usaha pemeliharaan kebugaran jasmani mahasiswa melalui program latihan olahraga mandiri di rumah dapat menjadi solusi praktis yang bermanfaat untuk pemeliharaan kondisi fisik. Pemeliharaan kondisi fisik hanya bisa dilakukan dengan membiasakan pola hidup aktif melalui aktivitas latihan atau olahraga. Program olahraga mandiri di masa pandemi COVID-19 perlu diarahkan pada tujuan untuk pemeliharaan kebugaran jasmani yang berkaitan dengan kesehatan (health related physical fitness). Komponen utama yang harus menjadi sasaran latihan kebugaran adalah kesehatan kardiovaskular, kekuatan dan daya tahan otot serta kelentukan. Merujuk pada pengaruh serangan virus COVID-19 yang dapat melemahkan sistim imun tubuh maka dipandang perlu untuk melakukan upaya pemeliharaan dan peningkatan imunitas tubuh melalui latihan fisik yang adekuat agar menjaga kekuatan dan daya tahan tubuh tetap dalam kondisi optimal (Tapo \& Bile, 2020:55-58). Selain menunjang pemeliharaan kebugaran jasmani, latihan fisik yang adekuat juga berkontribusi penting dalam kinerja kognitif seseorang (Kim et al., 2020:13). Untuk itu, usaha pemeliharaan kebugaran jasmani melalui aktivitas latihan fisik, perlu dilakukan secara teratur dan berkesinambungan sehingga dapat memberikan manfaat jangka panjang yang lebih maksimal.

Aktivitas latihan kebugaran dapat dilakukan dengan berbagai cara, salah satu diantaranya adalah dengan menggunakan latihan bodyweight. Latihan bodyweight merupakan salah satu bentuk aktivitas latihan fisik yang memanfaatkan berat badan sendiri sebagai beban latihan sehingga meminimalisir resiko terjadinya cedera. Pendekatan latihan bodyweight bertujuan untuk melatih aspek kekuatan dan daya tahan otot, meningkatkan kelentukan (Anholt, 2013:13-15) serta memperbaiki kondisi kebugaran fisik secara umum (Kuslikis, 2012:2-5). Secara praktis, latihan bodyweight sangat relevan untuk dilakukan selama masa pandemi COVID-19 karena dapat dilakukan secara mandiri di rumah, tidak membutuhkan fasilitas latihan yang mahal, durasi latihan relatif lebih singkat dengan sasaran kelompok otot yang dilatih lebih banyak, serta tidak memiliki resiko mengalami cedera yang berarti selama latihan (Bile \& Suharjana, 2019:35-36). Aktivitas fisik dalam pendekatan latihan bodyweight dapat dengan mudah diarahkan untuk melatih beberapa komponen kebugaran jasmani yang menyangkut dengan kesehatan (health related physical fitness) yang meliputi komponen kekuatan otot, daya tahan otot, kelentukan serta komposisi tubuh. 
Dengan merujuk pada berbagai hal yang berkaitan dengan kondisi penyebaran COVID-19 maka kegiatan pengabdian kepada masyarakat ini berfokus pada beberapa hal penting yang meliputi; 1) peningkatan pemahaman siswa/i tingkat SMA mengenai pentingnya pemeliharaan kebugaran jasmani di masa pandemi COVID-19, 2) penguasaan keterampilan fisik untuk pemeliharaan kebugaran jasmani siswa/i tingkat SMA di masa pandemi COVID-19, 3) peningkatan pemahaman siswa/i tingkat SMA tentang prinsip-prinsip dasar program latihan kebugaran jasmani yang baik dan benar meliputi; bentuk latihan, tujuan dan sasaran latihan, intensitas latihan, frekuensi latihan, serta durasi latihan.

\section{METODE PELAKSANAAN}

Kegiatan pengabdian ini dilaksanakan selama 2 hari (17-18 April 2020). Dengan menggunakan pendekatan pelatihan dan pendampingan secara langsung, kegiatan pengabdian kepada masyarakat ini ditujukan untuk siswa/i tingkat SMA yang berdomisili di wilayah Desa Naruwolo, Kec. Jerebu'u, Kab. Ngada. Kegiatan ini fokus pada memberikan edukasi dan pelatihan jenis-jenis latihan kebugaran jasmani berbasis bodyweight yang dapat dilakukan secara mandiri dirumah sehingga level kebugaran jasmani sebagai implikasi dari latihan kebugaran yang diberikan tidak diukur saat kegiatan pelatihan ini.

Adapun detail uraian program kegiatan pengabdian secara umum dapat diperhatikan seperti pada Tabel. 1 berikut.

Tabel 1. Uraian program kegiatan pengabdian

\begin{tabular}{|c|c|c|c|}
\hline No & Program Kegiatan & $\begin{array}{l}\text { Uraian Pelaksanaan Program } \\
\text { Kegiatan }\end{array}$ & $\begin{array}{l}\text { Ketercapaian } \\
\text { Program }\end{array}$ \\
\hline 1 & $\begin{array}{l}\text { Penjelasan materi } \\
\text { pentingnya } \\
\text { pemeliharaan } \\
\text { kebugaran jasmani } \\
\text { di masa pandemi } \\
\text { COVID-19. }\end{array}$ & $\begin{array}{l}\text { Tim pengabdi memberikan } \\
\text { pemahaman secara konsep dengan } \\
\text { cara menjelaskan pentingnya } \\
\text { pemeliharaan kebugaran jasmani di } \\
\text { masa pandemi COVID-19. }\end{array}$ & $\begin{array}{l}\text { Siswa/i memahami } \\
\text { pentingnya } \\
\text { pemeliharaan kebugaran } \\
\text { jasmani di masa } \\
\text { pandemi COVID-19. }\end{array}$ \\
\hline 2 & $\begin{array}{lr}\text { Penjelasan } & \text { materi } \\
\text { mengenai prinsip- } \\
\text { prinsip } & \text { latihan } \\
\text { kebugaran } & \text { jasmani } \\
\text { yang } & \text { meliputi; } \\
\text { bentuk latihan, } \\
\text { tujuan dan sasaran } \\
\text { latihan, intensitas } \\
\text { latihan, frekuensi } \\
\text { latihan, serta durasi } \\
\text { latihan. }\end{array}$ & $\begin{array}{l}\text { Tim pengabdi memberikan } \\
\text { pemahaman secara konsep dengan } \\
\text { cara menjelaskan prinsip-prinsip } \\
\text { latihan kebugaran jasmani yang } \\
\text { meliputi; bentuk latihan, tujuan dan } \\
\text { sasaran latihan, intensitas latihan, } \\
\text { frekuensi latihan, serta durasi } \\
\text { latihan. }\end{array}$ & $\begin{array}{l}\text { Siswa /i memahami } \\
\text { dengan baik prinsip- } \\
\text { prinsip latihan kebugaran } \\
\text { jasmani yang meliputi; } \\
\text { bentuk latihan, tujuan } \\
\text { dan sasaran latihan, } \\
\text { intensitas latihan, } \\
\text { frekuensi latihan, serta } \\
\text { durasi latihan. }\end{array}$ \\
\hline 3 & $\begin{array}{l}\text { Pendampingan } \\
\text { kegiatan latihan } \\
\text { kebugaran jasmani }\end{array}$ & $\begin{array}{l}\text { Tim pengabdi memberikan } \\
\text { pendampingan latihan kebugaran } \\
\text { jasmani secara langsung kepada } \\
\text { siswa/i }\end{array}$ & $\begin{array}{l}\text { Siswa melakukan latihan } \\
\text { kebugaran jasmani } \\
\text { dengan keterampilan } \\
\text { gerak yang baik. }\end{array}$ \\
\hline
\end{tabular}




\section{HASIL DAN PEMBAHASAN}

Hasil

Kegiatan pengabdian ini dilaksanakan di Desa Naruwolo, Kecamatan Jerebu'u, Kabupaten Ngada selama 3 hari yakni pada tanggal 09 - 11 April 2020. Seluruh rangkaian kegiatan pengabdian ini dilakukan di ruang terbuka yakni di lapangan sepakbola Desa Naruwolo. Siswa/i yang terlibat dalam kegiatan pelatihan ini secara keseluruhan berjumlah 20 orang siswa. Dengan metode ceramah dan praktikkum, seluruh peserta kegiatan dilibatkan secara langsung dalam setiap rangkaian kegiatan yakni mulai dari sesi penjelasan materi hingga sesi praktik latihan kebugaran jasmani. Seluruh kegiatan pengabdian dilakukan dengan tetap memperhatikan protokol kesehatan terkait COVID-19 seperti mencuci tangan, memakai masker dan menjaga jarak sehingga dipastikan kegiatan pengabdian ini tidak menimbulkan resiko penularan COVID-19. Rangkaian kegiatan pelatihan yang dilakukan adalah sebagai berikut.

\section{Tabel 2. Kegiatan pelatihan program olahraga kesehatan}

\begin{tabular}{|c|c|c|}
\hline No & $\begin{array}{c}\text { Materi } \\
\text { Kegiatan }\end{array}$ & Hasil \\
\hline 1 & $\begin{array}{l}\text { Penjelasan materi } \\
\text { pentingnya } \\
\text { pemeliharaan kebugaran } \\
\text { jasmani di masa } \\
\text { pandemi COVID-19. }\end{array}$ & $\begin{array}{l}\text { Kegiatan ini diawali dengan penjelasan materi pentingnya } \\
\text { pemeliharaan kebugaran jasmani di masa pandemi COVID-19 } \\
\text { oleh tim pengabdi dan dilanjutkan dengan sesi diskusi. Setiap } \\
\text { peserta terlibat aktif dalam kegiatan diskusi. Tim pengabdi } \\
\text { memberikan pertanyaan-pertanyaan stimulasi seputar isu } \\
\text { pemeliharaan kebugaran jasmani untuk memacu peserta } \\
\text { memahami dan mendalami materi. }\end{array}$ \\
\hline 2 & $\begin{array}{l}\text { Penjelasan materi } \\
\text { tentang prinsip-prinsip } \\
\text { latihan kebugaran } \\
\text { jasmani yang meliputi; } \\
\text { bentuk latihan, tujuan } \\
\text { dan sasaran latihan, } \\
\text { intensitas latihan, } \\
\text { frekuensi latihan, serta } \\
\text { durasi latihan. }\end{array}$ & $\begin{array}{l}\text { Tim pengabdi menjelaskan secara detail tentang prinsip-prinsip } \\
\text { latihan kebugaran jasmani. Setiap peserta dilibatkan secara } \\
\text { langsung selama sesi diskusi. Tim pengabdi memaparkan } \\
\text { substansi materi tentang prinsip latihan kebugaran jasmani yang } \\
\text { meliputi; variasi bentuk latihan kebugaran jasmani dengan } \\
\text { pendekatan bodyweight training, sasaran dan tujuan latihan } \\
\text { bodyweight, intensitas latihan, frekuensi serta durasi latihan } \\
\text { kebugaran jasmani yang proporsional bagi pelajar usia SMA. }\end{array}$ \\
\hline 3 & $\begin{array}{l}\text { Pendampingan kegiatan } \\
\text { latihan } \\
\text { jasmani. }\end{array}$ & $\begin{array}{l}\text { a. tim pengabdi terlibat langsung dalam memberikan contoh tiap } \\
\text { gerakkan latihan kebugaran jasmani. } \\
\text { b. mengarahkan peserta kegiatan untuk melakukan teknik } \\
\text { gerakan latihan kebugaran jasmani secara maksimal. } \\
\text { c. melakukan pendampingan kepada masing-masing peserta } \\
\text { saat melakukan kegiatan latihan kebugaran jasmani. } \\
\text { d. memperbaiki kesalahan peserta kegiatan terkait dengan } \\
\text { teknik dasar gerak latihan kebugaran jasmani. } \\
\text { e. memotivasi peserta kegiatan agar dapat melakukan latihan } \\
\text { mandiri di rumah masing-masing secara teratur dan } \\
\text { berkelanjutan. } \\
\text { f. mengarahkan peserta kegiatan untuk melakukan gerakan } \\
\text { latihan kebugaran jasmani sesuai dengan menu latihan yang } \\
\text { telah disediakan tim pengabdi meliputi bentuk latihan, } \\
\text { intensitas latihan, durasi latihan serta frekuensi latihan yang } \\
\text { adekuat dalam rangka menunjang pemeliharaan kebugaran } \\
\text { jasmani di masa pandemi COVID-19. } \\
\text { g. mengarahkan peserta kegiatan untuk mengevaluasi } \\
\text { kemampuan gerak fisik masing-masing untuk selanjutnya } \\
\text { dapat dijadikan acuan dalam menetapkan program latihan } \\
\text { kebugaran jasmani secara mandiri di rumah masing-masing. }\end{array}$ \\
\hline
\end{tabular}


Adapun program olahraga kesehatan yang diberikan kepada para peserta dalam kegiatan pengabdian kepada masyarakat ini adalah latihan kebugaran jasmani menggunakan latihan bodyweight. Pendekatan latihan bodyweight ini menggunakan bentukbentuk latihan bodyweight yang pada model latihan BBC Exercise (Bile \& Suharjana, 2019:33-36). Adapun bentuk-bentuk latihan bodyweight yang dimaksud dapat diperhatikan pada tabel program latihan berikut.

Tabel 3. Program latihan kebugaran jasmani menggunakan latihan bodyweight

\begin{tabular}{lllll}
\hline Tahapan Latihan & Bentuk Gerakan & Set & Reps. & Durasi \\
\hline Peregangan & Peregangan statis & - & - & 3 menit \\
\hline Pemanasan & Jogging di tempat & 1 & - & 1 menit \\
& Jumping jacks & 1 & - & 1 menit \\
\hline \multirow{5}{*}{ Latihan Inti } & Static squat & 2 & 2 & $30 \mathrm{dtk}$ \\
& Knee push up & 2 & 2 & $30 \mathrm{dtk}$ \\
& Basic crunch & 2 & 2 & $30 \mathrm{dtk}$ \\
& Side crunch & 2 & 2 & $30 \mathrm{dtk}$ \\
& Basic squat & 2 & 2 & $30 \mathrm{dtk}$ \\
& Touch squat & 2 & 2 & $30 \mathrm{dtk}$ \\
& Walk out & 2 & 2 & $30 \mathrm{dtk}$ \\
\hline \multirow{5}{*}{ Pendinginan } & Jump squat & 1 & - & $30 \mathrm{dtk}$ \\
& Tuck hold & 1 & - & $30 \mathrm{dtk}$ \\
& Plank & 1 & - & $30 \mathrm{dtk}$ \\
& Single leg-arm extension & 1 & - & $30 \mathrm{dtk}$ \\
\hline
\end{tabular}

\section{Pembahasan}

Sesuai dengan hasil evaluasi kegiatan pengabdian yang dilakukan, dapat disimpulkan beberapa hal sebagai berikut.

1. Secara umum, kegiatan pengabdian memberikan dampak yang baik bagi para peserta kegiatan (siswa/i SMA) dalam aspek pemahaman akan pentingnya pemeliharaan kebugaran jasmani di masa pandemi COVID-19 melalui program olahraga kesehatan. Para peserta kegiatan antuasias dan proaktif mengikuti semua item kegiatan pengabdian mulai dari awal hingga akhir baik pada sesi diskusi maupun praktik latihan kebugaran.

2. Adanya peningkatan keterampilan gerak para peserta kegiatan yakni gerak latihan kebugaran jasmani dengan menggunakan pendekatan latihan bodyweight. Setelah mengikuti beberapa tahapan simulasi dan latihan kebugaran jasmani, para peserta memiliki keterampilan gerak yang baik. Latihan yang dilakukan secara bertahap dan berulang-ulang mulai dari gerakan pemanasan, gerakan inti hingga pendinginan dapat dilakukan dengan baik oleh semua peserta.

3. Peserta kegiatan mengharapkan keberlanjutan prpogram-program pengabdian sejenis yang dapat memberikan manfaat secara langsung bagi aspek pemeliharaan kesehatan dan kebugaran fisik selama masa pandemi COVID-19.

Penyelenggaraan kegiatan pelatihan program olahraga kesehatan untuk pemeliharaan kebugaran jasmani ini memberikan dampak yang baik bagi perubahan pola pikir pelajar mengenai pentingnya upaya-upaya pemeliharaan kebugaran jasmani selama 
masa pandemi COVID-19 melalui program-program latihan olahraga kesehatan. Pendampingan yang dilakukan secara langsung selama kegiatan pengabdian perlu dilakukan secara teratur dan bersifat kontinyu sehingga dapat memberikan manfaat yang baik tidak hanya menyangkut peningkatan pola pemahaman pelajar tentang urgensi pemeliharaan status kebugaran fisik selama masa pandemi COVID-19 tetapi lebih dari itu dapat membiasakan mereka untuk rutin melatih keterampilan gerak fisik melalui latihanlatihan olahraga kesehatan yang adekuat dengan pengaturan intensitas, durasi, serta frekuensi latihan yang disesuaikan dengan kemampuan fisik masing-masing (Bile, 2019:36). Pendekatan latihan kebugaran jasmani melalui latihan bodyweight secara teknis dapat dilakukan secara mandiri di rumah tanpa harus menggunakan alat bantu latihan yang mahal namun dapat memberikan manfaat yang baik untuk tujuan pemeliharaan kebugaran jasmani (Bile \& Suharjana, 2019:35-36). Dengan memanfaatkan berat atau bobot tubuh sendiri, pelajar dapat melakukan berbagai variasi bentuk gerak latihan bodyweight untuk tujuan pemeliharaan kebugaran fisik agar tetap dalam keadaan optimal. Selain menunjang kebugaran fisik yang optimal, latihan kebugaran jasmani yang dilakukan secara teratur dan bersifat kontinyu juga dapat memberikan manfaat yang baik bagi peningkatan kinerja kognitif seseorang (Ruotsalainen et al., 2020:1-3).

Pelatihan dan pendampingan yang dilakukan ini berfokus pada menstimulasi pola pikir pelajar SMA agar dapat memiliki pemahaman yang baik mengenai pentingnya melakukan berbagai upaya pemeliharaan kebugaran jasmani selama masa pandemi COVID19 melalui berbagai bentuk kegiatan latihan kebugaran jasmani yang mudah dilakukan secara mandiri di rumah masing-masing tanpa harus melibatkan banyak orang. Lebih dari itu, pendampingan yang diberikan secara langsung selama kegiatan pelatihan, dititikberatkan pada tujuan untuk merangsang respon gerak fisik para pelajar agar terbiasa dengan berbagai variasi latihan kebugaran fisik melalui pendekatan bodyweight. Hal ini bertujuan agar para siswa memiliki keterampilan gerak fisik yang baik dan memadai agar dapat menunjang segala bentuk kebutuhan kinerja fisik sehari-hari di rumah selama masa pandemi COVID-19.

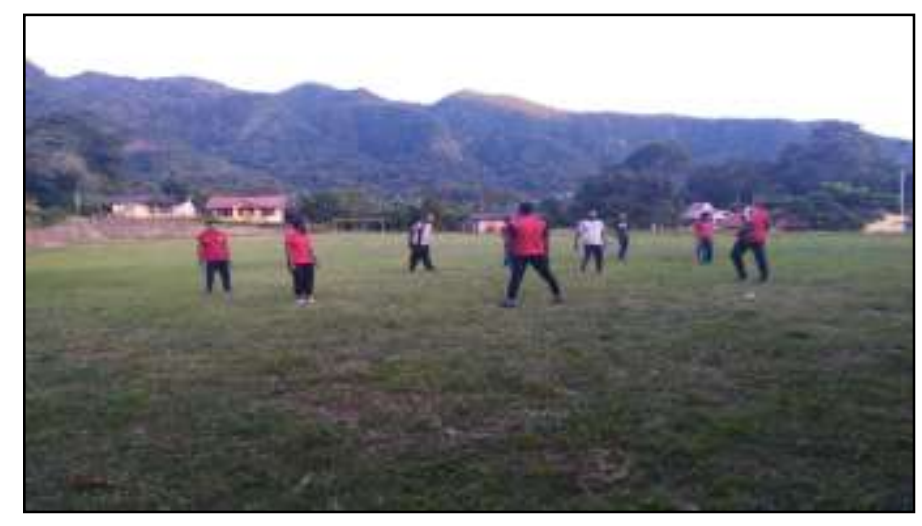

Gambar 1. Pendampingan Latihan Kebugaran 


\section{KESIMPULAN}

Ada beberapa hal yang dapat disimpulkan dari kegiatan pengabdian ini adalah; penyelenggaraan kegiatan pengabdian dengan pendekatan pendampingan program olahraga kesehatan bagi pelajar perlu untuk dilakukan agar dapat memberikan manfaat lebih bagi para siswa di masa pandemi COVID-19. Melalui kegiatan pelatihan kebugaran jasmani, siswa distimulasi untuk selalu menerapkan pola hidup aktif dan sehat selama pandemi COVID-19 yakni dengan menerapkan protokol kesehatan terkait COVID-19 serta rutin menjalankan program latihan olahraga kesehatan yang dapat dilakukan secara mandiri di rumah masing-masing. Adapun jenis latihan yang direkomendasikan untuk dapat dilakukan dirumah adalah latihan bodyweight (seperti pada tabel 3). Dengan kegiatan pelatihan yang dilakukan, para peserta (siswa SMA) memperoleh pemahaman serta keterampilan gerak yang baik berkaitan dengan upaya pemeliharaan kebugaran fisik selama pandemi COVID-19 melalui latihan olahraga kesehatan.

\section{DAFTAR PUSTAKA}

A. Wahyuri (2017). Pengembangan model latihan kebugaran jasmani berbasis aktivitas bermain, Jurnal Mensana 2(2), pp. 14-18, Oct. 2017. DOI:10.24036/jm.v2i2.19

Anholt, A. (2013). 3 In 1 exercise samples. Google play Book. Ebook.

Bachmann, J. M., DeFina, L. F., Franzini, L., Gao, A., Leonard, D. S., Cooper, K. H., Berry, J. D., \& Willis, B. L. (2015). Cardiorespiratory Fitness in Middle Age and Health Care Costs in Later Life. Journal of the American College of Cardiology, 66(17), 1876-1885. https://doi.org/10.1016/j.jacc.2015.08.030

Bile, R. L., \& Suharjana. (2019). Efektivitas Penggunaan Model Latihan Kebugaran “ BBC Exercise " Untuk Pemeliharaan Kebugaran Jasmani Mahasiswa. SPORTIVE : Journal of Physical Education, Sport and Recreation, 3(September), 30-37.

Djoko Pekik Irianto. (2017). Gizi Keluarga dan Olahragawan. 106-109.

Hale, R., Green, J., Hausselle, J., Saxby, D., \& Gonzalez, R. V. (2018). Quantified in vitro tibiofemoral contact during bodyweight back squats. Journal of Biomechanics, 79, $21-$ 30. https://doi.org/10.1016/j.jbiomech.2018.07.002

Kim, J. K., Son, W. II, Sim, Y. J., Lee, J. S., \& Saud, K. O. (2020). The study of health-related fitness normative scores for nepalese older adults. International Journal of Environmental Research and Public Health, 17(8), 1-15. https://doi.org/10.3390/ijerph17082723

Knaeps, S., Bourgois, J. G., Charlier, R., Mertens, E., Lefevre, J., \& Wijndaele, K. (2016). Ten-year change in sedentary behaviour, moderate- to-vigorous physical activity, cardiorespiratory fitness and cardiometabolic risk: independent associations and mediation analysis. British Journal of Sports Medicine, 0 (August), 1-7. https://doi.org/10.1136/bjsports-2016-096083

Lipecki, K., \& Rutowicz, B. (2015). The impact of ten weeks of bodyweight training on the level of physical fitness and selected parameters of body composition in women aged 21-23 years. Pol. J. Sport Tourism 2015, 22, 64-73. 
Ruotsalainen, I., Gorbach, T., Perkola, J., Renvall, V., Syväoja, H. J., Tammelin, T. H., Karvanen, J., \& Parviainen, T. (2020). Physical activity, aerobic fitness, and brain white matter: Their role for executive functions in adolescence. Developmental Cognitive Neuroscience, 42. https://doi.org/10.1016/j.dcn.2020.100765

Tapo, Y. B. O., \& Bile, R. L. (2020). Efektivitas penggunaan model latihan olahraga pernapasan MONACORS untuk pemeliharaan kesehatan fungsi paru bagi mahasiswa dalam menghadapi pandemi COVID-19. Ejurnal IMEDTECH, 4(2), 54-65. 